\title{
A Cradle-to-Gate Framework for Optimizing Material Production in Road Construction
}

\author{
Hassanean Jassim, Jan Krantz, Weizhuo Lu, Thomas Olofsson \\ Luleå University of Technology, Luleå, Sweden \\ Contact: hassanean.jassim@ltu.se
}

\begin{abstract}
In road construction, large quantities of raw materials are extracted and transported during several stages of its life cycle. Consequently, processing and preparation of raw materials for different purposes inevitably result in considerable amount of energy use and emissions of air pollutants. The Swedish Transportation Administration has an ambition to minimize environmental impacts from transport infrastructure projects by, for instance, reducing the energy use and emissions of greenhouse gases. This can be achieved by implementing specific strategies and techniques during various stages throughout the life cycle of the project. In this paper a framework is proposed to manage the energy use and greenhouse gases emissions from raw materials extraction processes in road construction projects. A prototype is developed based on the framework and demonstrated in a small case study.
\end{abstract}

Keywords: extracting raw materials; LCA; energy used; emission; product stage; road construction

\section{Introduction}

Reducing greenhouse gas (GHG) emissions and energy use in road construction processes is becoming an increasingly important topic for the Swedish Transport Administration (STA) [1]. Material extraction and production processes in road projects contribute considerably to greenhouse gas (GHG) emissions [2, 3]. Rock quarries or borrow pits are commonly used to extract materials for producing the aggregate used as base course, sub base or as a compound in bound layers of the road. This is often a time consuming process that involves several steps including rock extraction, hauling, loading and crushing in several steps [4]. Rock extraction is often conducted by drilling holes in specific patterns which are filled with explosives [5]. The result is fragmented rock of different dimensions from fines to coarse fragments [6]. Aggregates used in road projects usually require certain particle size intervals; hence particles that are too fine are waste [7], whereas particles too coarse can be in need of additional blasting [8]. After blasting the rock it is often crushed to more uniform particle sizes before used in roads. Rock crushing is conducted at crushing plants usually containing several different crushers, screens and conveyors in order to produce aggregates with different particle sizes $[4,8]$. These processes in combination constitute cradle-to-gate when viewed from a life cycle perspective [9]. This includes all steps occurring prior to the material being transported to the construction site [10]. Life cycle assessments (LCA) tools are particularly useful for assessing environmental impacts throughout the different stages of the life cycle of products or processes [11]. However, despite the large number of previous LCA studies of road projects [12, 13, 14, 15], limited attention has been put on the energy use and GHG emissions of material production processes off-site.

In this study, we propose a framework that can support the selection of borrow pit locations, extraction methods, crushing and equipment. A 
cradle to gate prototype is developed based on the framework LCA components for aggregate production in the road projects. The use of this prototype is illustrated in a small demonstration of one selected to borrow pit. The findings suggest that by considering the energy use and GHG emissions in the planning phase at borrow pits, the environmental impacts from aggregate production can be mitigated.

\section{A framework for cradle-to-gate assessment of embodied energy use and GHG emission}

Since late 1960s, Life Cycle Assessment (LCA) has been used as the environmental management tool in construction to estimate environmental impact $[2,12,16,17]$. LCA is seeking out to mitigate the environmental impacts during construction by identifying areas of high importance [18]. LCA was developed for the evaluation environmental implications of the energy and material use with the associated with the materials' production along the entire life cycle [19]. Therefore, in order to reduce energy consumption, pollutant emission, waste production and land use, comprehensive planning and design of extraction activities and operations is essential [20].

Cradle-to-gate stage consists of the assessment of "upstream activities" from the raw material acquisition "cradle" to the factory outlet "gate" (see Figure 1) (i.e., before it is transported to the site construction) $[10,16,21]$. The environmental impact from road construction operations (i.e. embodied energy and GHG emissions) is dependent on the location where the extraction of raw materials is made [22]. Studies show that the production and transport of raw materials such as sand, gravel and crushed stone represents the largest environmental impacts [23, 24]. Therefore, procedures to evaluate extraction of materials from different sites and quarries are important to mitigate these effects, such as type of fuel and energy used [25]. Also, the optimum utilization of raw materials over a road's life cycle will reduce the environmental burden [26].

\begin{tabular}{|c|c|c|c|c|c|}
\hline \multirow{4}{*}{ 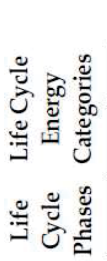 } & \multicolumn{5}{|c|}{ ROAD LIFE CYCLE ENERGY INFORMATION } \\
\hline & Indirect Energy & \multicolumn{2}{|c|}{ Direct Energy } & & Indirect Energy \\
\hline & \multicolumn{3}{|c|}{ Initial Embodied Energy } & \multicolumn{2}{|c|}{ Operational \& Embodied Energy } \\
\hline & Product & Transportation & Construction & $\begin{array}{l}\text { Operation \& } \\
\text { Maintenance } \\
\end{array}$ & End-of-Life \\
\hline 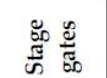 & Cradle to gate & $\begin{array}{l}\text { Gate to site } \\
\text { construction }\end{array}$ & $\begin{array}{l}\text { Construction to } \\
\text { operation gate }\end{array}$ & \multicolumn{2}{|c|}{ Operation gate to end life (grave) } \\
\hline 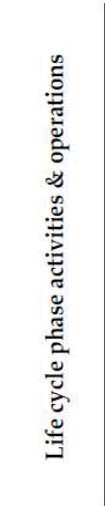 & $\begin{array}{l}\text { 1- Extraction of } \\
\text { raw materials } \\
\text { 2- Production of } \\
\text { road construction } \\
\text { material } \\
\text { 3-Transport of } \\
\text { road construction } \\
\text { materials to } \\
\text { stockpile or } \\
\text { factory } \\
\text { 4- Processing \& } \\
\text { Manufacturing }\end{array}$ & $\begin{array}{c}\text { 1-Transport } \\
\text { construction } \\
\text { products to/of } \\
\text { construction site } \\
\text { throughout } \\
\text { construction } \\
\text { period }\end{array}$ & $\begin{array}{l}\text { 1-Machineries \& } \\
\text { equipment use in } \\
\text { different } \\
\text { activities and } \\
\text { operations } \\
\text { throughout } \\
\text { construction (i.e. } \\
\text { earthwork \& } \\
\text { pavement work) } \\
\text { 2- Transport } \\
\text { materials on site } \\
\text { construction } \\
\text { 3- Use by various } \\
\text { facilities within } \\
\text { site construction } \\
\text { configurations }\end{array}$ & $\begin{array}{l}\text { 1- Facilities and } \\
\text { annexes for } \\
\text { road service } \\
\text { such as (signs, } \\
\text { lightning, } \\
\text { heating, } \\
\text { cleaning, } \\
\text { installations, } \\
\text { road furniture, } \\
\text { etc.). } \\
\text { 2- Regular } \\
\text { maintenance for } \\
\text { structure \& } \\
\text { pavement } \\
\text { 3- Repair } \\
\text { winter } \\
\text { services } \\
\end{array}$ & \begin{tabular}{|c|} 
1- Demolition; \\
machineries \& \\
equipment use to \\
materials removal \\
2- Transport of \\
removal \\
materials to \\
recycling zones \\
3- Rehabilitation \\
of demolition \\
area \\
4- Recycling of \\
removal \\
materials
\end{tabular} \\
\hline \multirow{2}{*}{ 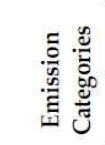 } & \multicolumn{3}{|c|}{ Upstream \& Manufacturing Emissions } & \multirow{2}{*}{ Operating Stage } & $\begin{array}{c}\text { Downstream } \\
\text { Emissions }\end{array}$ \\
\hline & \multicolumn{3}{|c|}{ Embodied Emissions } & & $\begin{array}{l}\text { Embodied } \\
\text { Emissions }\end{array}$ \\
\hline
\end{tabular}

Figure 1. Life cycle phases, energy use and emission in road construction project $[4,12,22]$ 
The initial embodied energy in the road and infrastructure projects includes the main components for the realization of the road structure such as acquisition of construction materials (extraction, production, and transportation to site), manufacturing and installing various items related to the road structure but also maintenance and rehabilitation, and demolition and waste disposal [22, 27, 28]. Almost all operational energy use comes from traffic [16].

Embodied energy from the extraction raw materials is just one of the environmental impacts associated with upstream processes in constructions of roads $[27,29]$. Two types of emissions is associated with extraction of raw materials, emissions from "crushing of natural materials" and emissions from the energy used to operate machinery and equipment [29].

The proposed prototype aims to support the selection and operations of quarries or borrows pits used in road construction projects based on the cradle-to-gate environmental impact perspective for raw material production.

\section{Prototype for optimal operation of material production for road construction}

A goal of the prototype is to support planning and operation of material production for road construction. The assessment of embodied energy and GHG emissions is based on the product cradle-to-gate phase shown in figure 1 . The prototype for selection and operation of quarries and borrows pits is divided into seven steps, see figure 2 :

1) Evaluation of extraction locations: First geological and geotechnical information should be collected for the whole road construction site, e.g. bill of quantities of construction materials as well the quantities of raw materials required for the construction project. In addition, geological and geotechnical information of possible extraction location for raw materials should also be collected in order to avoid contaminated areas, organic and landfill disposals, poor raw material that needs modification before used. Based on this information the best location(s) should be evaluated regarding quantities and qualities of the extracted materials. The extraction method should also be selected to meet production target with low level of energy use and emission.

2) Estimation of energy use $\left(E_{e m}\right)$ and emissions $\left(G H G_{e m}\right)$ from selected extraction method: Different extraction methods use specific type of energy resources (e.g. excavating, digging, blasting and dredging). In case the extraction methods for the location selected can't meet the project environmental requirement another location should be considered.

3) Estimating energy use ( $\left.E_{e \& m}\right)$ and emissions from extraction equipment \& machineries $\left(G H G_{e \& m}\right)$ : Equipment and machineries such as diggers, excavators, wheel loaders, crawler tractors, drillers etc. consumes large amounts of energy (both fossil fuels \& electricity) in the acquisition and extraction of materials [30]. Selection can be done by comparing productivity of equipment with the level of energy use and emissions.

4) Estimating energy ( $\left.E_{c \& s}\right)$ use and emission $\left(G H G_{c \& s}\right)$ from crusher plant and sorting zones: The selection of crusher plants \& sorting zones depended on the plant model used and/or availability of energy sources and economic state of work area. The quantity of pollutant to land, air and water through emission from the plant must also be taken into consideration.

5) Estimating energy use and emission of different elements related to the extraction and transportation of materials:

a. Energy use from trucks and dumpers or conveyor $\left(E_{t \& d}\right)$ and their emissions $\left(G H G_{t \& d}\right)$ : Transport of road construction materials to stockpile or factory is a significant component that have effect on the amount of energy consumed and emission at upstream phases of the road project. [31]

b. Energy use $\left(E_{a r}\right)$ and emissions $\left(G H G_{a r}\right)$ from building service routes from extraction location to site: Often quarries and borrow pits are located at non-serviced areas, and it 
needs be connected with main road, factory and site construction.

c. Energy use $\left(E_{f \& c}\right)$ and emission from site facilities $\left(G H G_{f e c}\right)$ and configurations: Site facilities and configurations on the extraction location should be included such as administration, accommodation, sanitary \& sewage systems, service \& maintenance etc. for short term extraction or long term extraction (e.g. borrow pits or quarries).

d. Energy use $\left(E_{s m}\right)$ and emission $\left(G H G_{s m}\right)$ from Stockpiles: Stockpile areas generate environmental pressure on the natural land surrounding in the industrial area through effect on natural sources [32, 33].

e. Energy use $\left(E_{r m}\right)$ and emission $\left(G H G_{r m}\right)$ from recycling of materials: The energy use is dependent on equipment and machineries used in removal, processing, transporting of recycled materials [10].

6) The embodied energy $\left(E_{e l}\right)$ and emission $\left(G H G_{e l}\right)$ from step 2 to 5 can now be summarized, see Eq (1) and (2), for the selected location of extraction together with the production quantities of construction materials.
7) In this step, the performance of the extraction location of can be made comparing the final outputs of material with the amount of embodied energy and emission from activities and operations. Comparison is achieved based on the environmental perspectives for location of extraction or site construction. In case of the results are out of site boundaries where should go back to first step of the prototype, in order to select and test other options. Thereby, a final decision making about an optimum productivity rate of the raw construction materials with their environmental implications during planning stages. As well as, it is possible to get on the evaluation values for energy consumption and emission for each one cubic meter or each ton of material produced. At last of this stage, the raw material producing to be moved to the factory gate, or to stockpile area, or to disposal area.

$\mathrm{E}_{e l}=E_{e m}+E_{e \& m}+E_{c \& s}+E_{t \& d}+E_{a r}+E_{f \& c}+E_{s m}+E_{r m}$

The energy is expressed as $\mathrm{kWh}$ per tonnes produced material.

$\mathrm{GHG}_{e l}=G H G_{e m}+G H G_{e \& m}+G H G_{c \& s}+G H G_{t \& d}+G H G_{a r}+$

The emission is expressed as tonnes $\mathrm{CO}_{2}$ eqivalent emission tonnes per tonnes produced material.

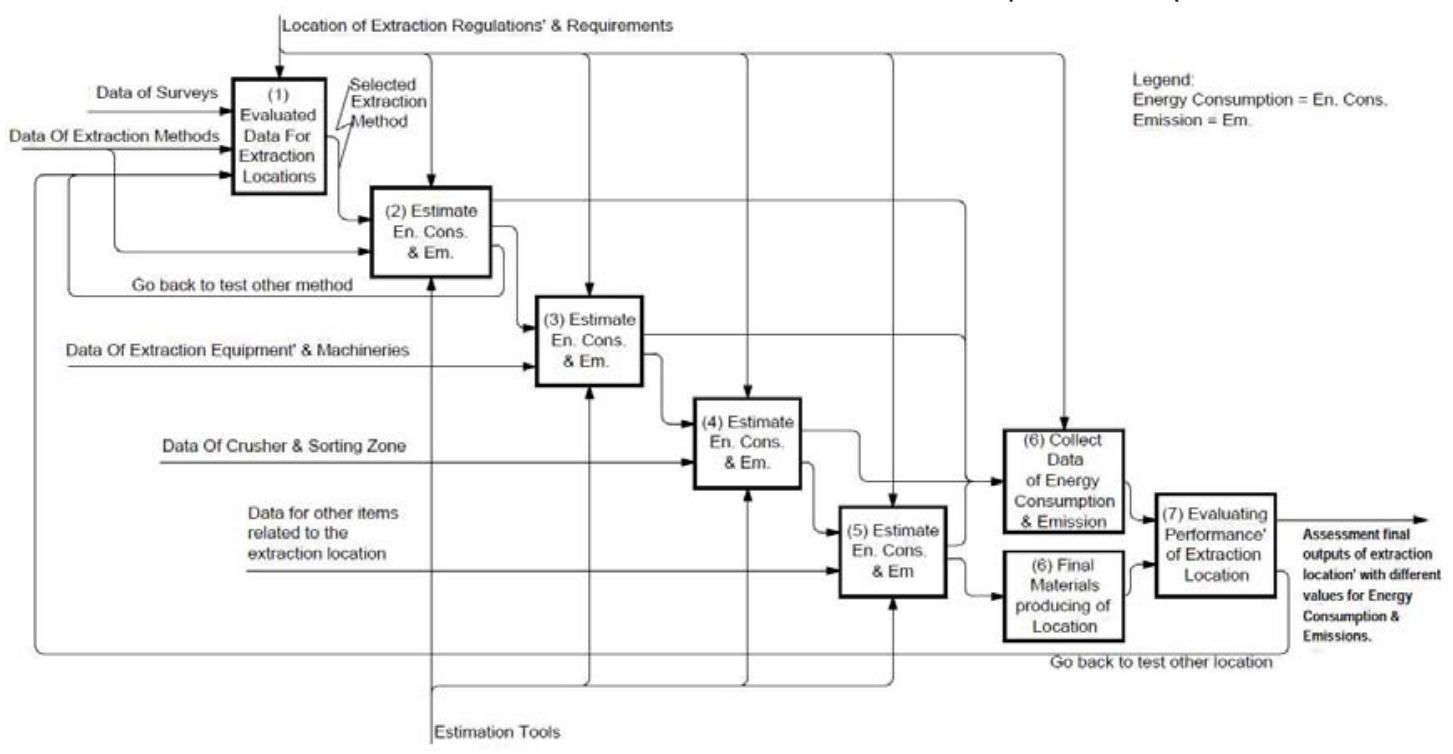

Figure 2: Prototype proposed for optimal outputs of extraction location in road construction. 


\section{Demonstration of the Prototype}

In order to demonstrate the prototype a hypothetical case study was performed on the selection of extraction method and crushing plant in a borrow pit in a road construction project. Data for the comparison was collected from various studies $[34,35,36,37,38,39]$. Two extraction methods and two crushing plants are evaluated in terms of equivalent $\mathrm{CO}_{2}$ emissions resulting in a total comparison of four alternatives. The comparison of methods and equipment are based on the production of 10000 tonnes of base course. Table 1 shows background data and the $\mathrm{CO}_{2}$ emissions for the evaluated extraction methods. Due to the waste generated in each extraction method additional material need to be extracted to compensate for the waste. The productivity of the drill rigs is based on productivity diagrams [36], and the diesel use is calculated through a method presented in [37].

Table 1. Background data and resulting $\mathrm{CO} 2$ emissions of each extraction method.

\begin{tabular}{ccc}
\hline Method & $\begin{array}{c}\text { Extraction } \\
\text { method A }\end{array}$ & $\begin{array}{c}\text { Extraction } \\
\text { Method B }\end{array}$ \\
\hline Drill rig & $\begin{array}{c}\text { Tamrock DHA } \\
600 S(125 \mathrm{~kW})\end{array}$ & $\begin{array}{c}\text { Atlas Copco Roc } \\
410 \mathrm{HC}(47 \mathrm{~kW})\end{array}$ \\
\hline $\begin{array}{c}\text { Productivity } \\
\text { (tonnes/h) }\end{array}$ & $392[36,37,5]$ & $128[36,37,5]$ \\
\hline Diesel use $(\mathrm{kg} / \mathrm{h})$ & $14.0[36,37,5]$ & $5.4[36,37,5]$ \\
\hline Bore hole sizes & $76[5]$ & $51[5]$ \\
\hline $\begin{array}{c}\text { Explosives } / \text { tonne } \\
\text { rock }\end{array}$ & $0.18[5]$ & $0.21[5]$ \\
\hline Waste $(\%)$ & $0.25[5]$ & $0.20[5]$ \\
\hline Total diesel use & 476 & 527 \\
\hline Total $\mathrm{CO}_{2}$ & 1965 & 2171 \\
\hline
\end{tabular}

The two crushing plants evaluated shown in table 2 use both electricity and diesel.

Table 2. Background data and resulting $\mathrm{CO} 2$ emissions of each crushing plant.

\begin{tabular}{ccc}
\hline Crushing plant & $\begin{array}{c}\text { Bjärsgård } \\
{[38]}\end{array}$ & $\begin{array}{c}\text { Skanska } \\
{[39]}\end{array}$ \\
\hline diesel use (kg/tonne) & 0.83 & 0.68 \\
\hline electricity use (kWh/tonne) & 1.50 & 2.65 \\
\hline Total diesel use $(\mathrm{kg})$ & 8320 & 6822 \\
\hline Total electricity use $(\mathrm{kWh})$ & 15000 & 26500 \\
\hline
\end{tabular}

\begin{tabular}{ccc}
\hline CO2 from diesel use $(\mathrm{kg})$ & 26790 & 21968 \\
\hline CO2 from electricity use $(\mathrm{kg})$ & 300 & 530 \\
\hline Total $\mathrm{CO}_{2}$ emissions $(\mathrm{kg})$ & 27090 & 22498 \\
\hline
\end{tabular}

The total $\mathrm{CO}_{2}$ emission of each combination of crusher and extraction method is presented in table 3.

Table 2. Total $\mathrm{CO}_{2}$ emissions of each combination of alternatives.

\begin{tabular}{lc}
\hline \multicolumn{1}{c}{ Method and crushing plant } & CO $_{2}$ emissions (kg) \\
\hline Extraction method A +Skanska & 24463 \\
Extraction method B +Skanska & 24669 \\
Extraction method A +Bjärsgård & 29055 \\
Extraction method B +Bjärsgård & 29261 \\
\hline
\end{tabular}

\section{Discussion and Conclusions}

A prototype for the evaluation of the acquisition process of materials for road construction projects has been developed. The evaluation is divided into seven main assessment stages of environmental impact associated with production materials for road construction. The demonstration shows the application of the proposed prototype to assess the embodied energy and $\mathrm{CO}_{2}$ emission in a small case study. Four combinations of selection of extraction methods and crushers were evaluated with respect to emissions produced in the production of 10,000 tonnes of sub-course materials. These were generated from the two types of tested extraction methods with two types of crushers. The embodied energy used in the extraction of raw construction materials can also be evaluated by the prototype.

More case studies are needed to evaluate the proposed prototype, including emissions generated from the extracting processes of different methods, equipment and machineries used for transportation, crusher and sorting zone, and other items such as the build-up of temporary route, site facilities, and stockpile of materials.

Eventually, the prototype can be expanded to include other stages of the construction process such as the transportation of produced material to site and construction at the site. 


\section{References}

[1] The Swedish Transport Administration's efforts for improving energy efficiency and for climate mitigation. Trafikverket. Publication No. 2012:152.https://online4.ineko.se/trafikverket/Pr oduct/Detail/43997

[2] Menzies GF, Turan S, Banfill PF. Life-cycle assessment and embodied energy: a review. Proceedings of the Institution of Civil EngineersConstruction Materials 2007;160(4):135-144.

[3] Cass D, Mukherjee A. Calculation of greenhouse gas emissions for highway construction operations by using a hybrid lifecycle assessment approach: case study for pavement operations. J Constr Eng Manage 2011; 137(11):1015-1025.

[4] Trafikverket, Energy and Carbon Dioxide in Asphalt production. 2016.

[5] Ouchterlony F. The Swebrec (C) function: linking fragmentation by blasting and crushing. Min Technol 2005;114(1):29-44.

[6] Cho SH, Kaneko K. Rock fragmentation control in blasting. Materials transactions 2004;45(5):1722-1730.

[7] Guimaraes M, Valdes J, Palomino A, Santamarina J. Aggregate production: fines generation during rock crushing. Int J Miner Process 2007;81(4):237-247.

[8] Kulatilake P, Qiong W, Hudaverdi T, Kuzu C. Mean particle size prediction in rock blast fragmentation using neural networks. Eng Geol 2010;114(3):298-311.

[9] Huang Y, Hakim B, Zammataro S. Measuring the carbon footprint of road construction using CHANGER. International Journal of Pavement Engineering 2013;14(6):590-600.

[10] Harvey J, Kendall A, Saboori A. The Role of Life Cycle Assessment in Reducing Greenhouse Gas Emissions from Road Construction and Maintenance. 2015.

[11] Finnveden G, Hauschild MZ, Ekvall T, Guinée $\mathrm{J}$, Heijungs R, Hellweg $\mathrm{S}$, et al. Recent developments in life cycle assessment. J Environ Manage 2009;91(1):1-21.
[12] Stripple H. Life cycle assessment of road. A pilot study for inventory analysis. Rapport IVL Swedish Environmental Research Institute 2001:96.

[13] Treloar GJ, Love PE, Crawford RH. Hybrid lifecycle inventory for road construction and use. Journal of Construction Engineering and Management. 2004 Feb;130(1):43-9.

[14] Melanta S, Miller-Hooks E, Avetisyan HG. Carbon footprint estimation tool for transportation construction projects. J Constr Eng Manage 2012;139(5):547-555.

[15] Barandica JM, Fernández-Sánchez G, Berzosa Á, Delgado JA, Acosta FJ. Applying life cycle thinking to reduce greenhouse gas emissions from road projects. J Clean Prod 2013;57:79-91.

[16] Miliutenko S, Liljenström C, Bratteb $\varnothing \mathrm{H}$, Birgisdóttir H, Toller S, Lundberg K, Potting J. Life cycle impacts during early stages of road infrastructure planning: a case study in Sweden. Proc. Transport Research Arena 2014. 2014.

[17] Mundy J, Livesey K. Life Cycle Assessment for Construction Products: an introductory guide for manufacturers and specifiers. Forestry Commission; 2004.

[18] Hammond GP, Jones Cl. Embodied energy and carbon in construction materials. Proceedings of the Institution of Civil Engineers-Energy. 2008 May 1;161(2):87-98.

[19] Cabeza LF, Rincón L, Vilariño V, Pérez G, Castell A. Life cycle assessment (LCA) and life cycle energy analysis (LCEA) of buildings and the building sector: A review. Renewable and Sustainable Energy Reviews 2014;29:394-416.

[20] IFC. Environmental, Health, and Safety Guidelines for Construction Materials Extraction. International Finance Corporation, World Bank Group. APRIL 30, 2007.

[21] Construction Products Association. A guide to understanding the embodied impacts of construction, products. London: Construction Product Association. 2012.

[22] Jonsson D. Indirect energy associated with swedish road transports. European Journal of Transport and Infrastructure Research. 2007;7(3). 
[23] Muench S. Roadway Construction Sustainability Impacts: Review of Life-Cycle Assessments. Transportation Research Record: Journal of the Transportation Research Board. 2010 Aug 9(2151):36-45.

[24] MROUEH U. LIFE CYCLE ASSESSMENT OF ROAD CONSTRUCTION.. No. 17/2000. 2000.

[25] Der-Petrossian B, Johansson E. Construction and Environment-Improving energy efficiency. Building issues. 2000.

[26] Gambatese JA, Rajendran S. Sustainable roadway construction: Energy consumption and material waste generation of roadways. InConstruction Research Congress 2005 Apr (Vol. 183).

[27] Masters N. Sustainable use of new and recycled materials in coastal and fluvial construction: a guidance manual. : Thomas Telford; 2001.

[28] Simonsen M. Transport, energi og miljø. Sogndal, Norway: Vestlandsforskning. 2010.

[29] Chowdhury R, Apul D, Fry T. A life cycle based environmental impacts assessment of construction materials used in road construction. Resour Conserv Recycling 2010;54(4):250-255.

[30] Jullien A, Proust C, Martaud T, Rayssac E, Ropert C. Variability in the environmental impacts of aggregate production. Resources, Conservation and Recycling. 2012 May 31;62:1-3.

[31] Carlson A, Mellin A. Life cycle assessment of a road investment: estimating the effect on energy use when building a bypass road.

[32] Nisbet M, Van Geem MG, Gajda J, Marceau M. Environmental life cycle inventory of Portland cement and concrete. World cement. 1997 Apr;28(4):3.

[33] Chun Y, Claisse P, Naik TR, Ganjian E. Sustainable Construction Materials and Technologies: Proceedings of the Conference on Sustainable Construction Materials and Technologies, 11-13 June 2007, Coventry, United Kingdom. : CRC Press; 2007.

[34] No II WA. Emission Factor Documentation for AP-42 Section 11.19. 1995.
[35] Trafikverket, Energy and Carbon Dioxide in Asphalt production (EKA tool). 2015.

[36] Vägverket, Kapacitetsdata. BD 7 Umeå, Sweden. 1991.

[37] US EPA, Median Life, Annual Activity, and Load Factor Values for Nonroad Engine Emissions Modeling. Report: EPA-420-R-10-016. 2010.

[38] Lindén J, Koldioxid vid vägbyggnad - en fallstudie med jämförelse av alternativa byggnadssätt. Master's thesis, Lund University, Sweden. 2008.

[39] Andersson C, Gunnarsson H, Klimatpåverkan vid vägbyggnad beroende av vald konstruktion. Master's thesis, Halmstad University, Sweden. 2009. 